\title{
Severe Acute Kidney Injury after Multiple Honey Bee Stings
}

\author{
Satyanand Sathi ${ }^{1 *}$, Anil Kumar Garg ${ }^{1}$, Jaipal Chand ${ }^{2}$, Manoj Kumar Singh ${ }^{1}$, Virendra Singh Saini ${ }^{1}$, and Arvind Trivedi ${ }^{1}$ \\ ${ }^{1}$ Department of Medicine, S.M.M.H. Medical College, Saharanpur, Uttar Pradesh, India \\ ${ }^{2}$ Department of Medicine, Tarawati Super Specialty Hospital, Saharanpur, Uttar Pradesh, India
}

*Corresponding author: Satyanand Sathi, Assistant Professor, Department of Medicine, S.M.M.H. Medical College, Saharanpur, Uttar Pradesh, India, Phone: 7055054279; E-mail: satyanandsathi@yahoo.com

Received: 24 Apr, 2020 | Accepted: 14 May, 2020 | Published: 19 May, 2020

Citation: Sathi S, Garg AK, Chand J, Singh MK, Saini VS, et al. (2020) Severe Acute Kidney Injury after Multiple Honey Bee Stings. Int J Nephrol Kidney Fail 6(2): dx.doi.org/10.16966/2380-5498.195

Copyright: (C) 2020 Sathi S, et al. This is an open-access article distributed under the terms of the Creative Commons Attribution License, which permits unrestricted use, distribution, and reproduction in any medium, provided the original author and source are credited.

\section{Abstract}

There is insufficient data for honey bee sting-induced severe acute kidney injury (AKI) in the world population. A single sting can cause allergic reaction, but severity of prognosis is directly proportional to the number of stings. Mellitin is the principal part of honey bee venom. It is associated with phospholipase A2 (PLA2) and has vasoactive and hemolytic properties. Severe AKI may occur after a massive honey bee attack (more than one thousand stings) and this is because of multitude of factors, including direct toxicity of venom to the kidney tubules, hypotension, dehydration, rhabdomyolysis and intravascular hemolysis. Here, we report a 47-year-old male patient who presented with passage of cola colour urine and advanced azotemia after a multiple honey bee injury. Additional analyses revealed very high serum creatine phosphokinase, serum lactate dehydrogenase and urine myoglobin levels. The patient was treated with antihistamines, hydrocortisone, fluid infusion and hemodialysis. Renal failure recovered completely and the patient was discharged in a stable condition.

Keywords: Honey Bee Stings; Severe Acute Kidney Injury; Rhabdomyolysis; Venom

\section{Introduction}

In India, honey bee combs are uniformly distributed all over the populated regions. There is paucity of data reported on tremendous honey bee sting induced toxicity and multiple honey bee sting-induced acute kidney injury (AKI) in the world population. Multiple bee stings can cause shock, hypertension, bleeding, thrombocytopenia, hemolysis, skin necrosis, pancreatitis and AKI [1-5].

In any community, anaphylaxis incidence caused by insect stings is approximately 0.3 to 3 percent [6]. It has been noticed that the direct toxic effect of the venom can be fatal in a person after a tremendous honey bee sting attack and the estimated mortality rate has been reported from 15 to $25 \%$ [6,7]. Respiratory failure was the cause of death in one study which involved a small group of patients having massive honey bee sting attacks [7]. Insects having stings belong to the order Hymenoptera (ants, bees, wasps) [8].

The venom apparatus of hymenoptera order a species consists of a gland and a venom injecting system (sting). Peptides (mellitin, apamin), enzymes, amine and other proteins are the principal components of honey bee venom [8]. Out of them, mellitin is the most important component of honey bee venom and in association with phospholipase A2 (PLA2), it has vasoactive and hemolytic properties [6].

Arachidonic acid released from the cell membrane in the presence of PLA2 ultimately leads to the formation of inflammatory eicosanoids. There is systemic vasodilation and increased vascular permeability that leads to an increase uptake of venom by the blood vessels, which quickly spreads and decreases renal perfusion causing ischemic renal injury. Apamin is a peptide that acts as a neurotoxin causing degranulation of mast cells. Histamine is mostly the culprit damaging the vascular endothelium, as it can cause lysis of leukocytes, red blood cells and platelets. It has also been described that the direct toxic effect of the venom on skeletal muscles can cause rhabdomyolysis and myocardial necrosis [6].

The resultant anaphylaxis can cause shock and systemic vasodilation leading to hypoperfusion of many vital organs, including the kidneys. Anatomically, sting is the part of the female bee abdomen situated posteriorly, meant for egg lying (ovipositor) [9]. Bees use it as selfdefence when the victim's tissue is injected with the venom via the sting. After injecting the venom, sting is left at the site of inoculation by the bee [9].

\section{Case Report}

A 47-year-old male patient presented with a two day history of swelling of whole body with facial puffiness after multiple honeybee stings, passage of cola colour urine, decreased urine output and altered sensorium without any history of blunt trauma, fever, sore throat, impetigo, joint pain, smoking or alcohol drinking, There was no any history of NSAID abuse, type 2 diabetes mellitus or hypertension. On admission the patient had an altered sensorium, dyspneic, and a pulse rate of $112 /$ minute. His blood pressure was 
$88 / 58 \mathrm{~mm} \mathrm{Hg}$. On physical examination more than one thousand honey bee stings were found all over his back, face, chest, neck, ears and arms (Figures 1 and 2).

The patient's laboratory profile was as follows: total leukocyte count: $19,200 / \mathrm{mm}^{3}$, hemoglobin: $11.5 \mathrm{~g} / \mathrm{dL}$, platelet count: $1.32 \times 105 / \mathrm{mm}^{3}$, urine microscopy: white blood cell count: 5-6/high-power field, red blood cell count: $15-30 /$ high-power field, urinary protein: $1+$, urinary sugar: 0 , urinary $\mathrm{pH}$ : -6.8 , urine colour: cola, urine cast: muddy brown granular, serum glutamic pyruvic transaminase (SGPT): $138 \mathrm{U} / \mathrm{L}$, serum glutamic oxaloacetic transaminase (SGOT): $457 \mathrm{U} / \mathrm{L}$, serum bilirubin total: $0.8 \mathrm{mg} / \mathrm{dL}$, serum albumin: $4.0 \mathrm{~g} / \mathrm{dL}$, serum lactate dehydrogenase level: $995 \mathrm{IU} / \mathrm{L}$, serum creatine phosphokinase level: $7328 \mathrm{IU} / \mathrm{L}$, urine myoglobin: $885 \mathrm{ng} / \mathrm{mL}$ (normal $0-10$ ). HIV I and II: negative, anti-HCV: negative, HBsAg: negative, random blood sugar: $98 \mathrm{mg} / \mathrm{dL}$, serum creatinine: $7.8 \mathrm{mg} / \mathrm{dL}$, blood urea: $180 \mathrm{mg} /$ $\mathrm{dL}$, calcium: $8.4 \mathrm{mg} / \mathrm{dL}$, serum PO4: $5.6 \mathrm{mEq} / \mathrm{L}$, serum potassium: $5.5 \mathrm{mEq} / \mathrm{L}$, serum sodium: $143 \mathrm{mEq} / \mathrm{L}$, serum chloride: $112 \mathrm{mEq} / \mathrm{L}$, serum arterial blood gas: $\mathrm{pH} 7.30, \mathrm{pCO}_{2}: 28 \mathrm{~mm} \mathrm{Hg}, \mathrm{HCO} 3: 12.9$ $\mathrm{mEq} / \mathrm{L}, \mathrm{pO}_{2}: 102 \mathrm{~mm} \mathrm{Hg}$, anion gap: $18.1 \mathrm{mEq} / \mathrm{L}$. Ultrasound of the abdomen was suggestive of normal-sized kidneys with bilateral increased renal cortical echogenicity with intact corticomedullary

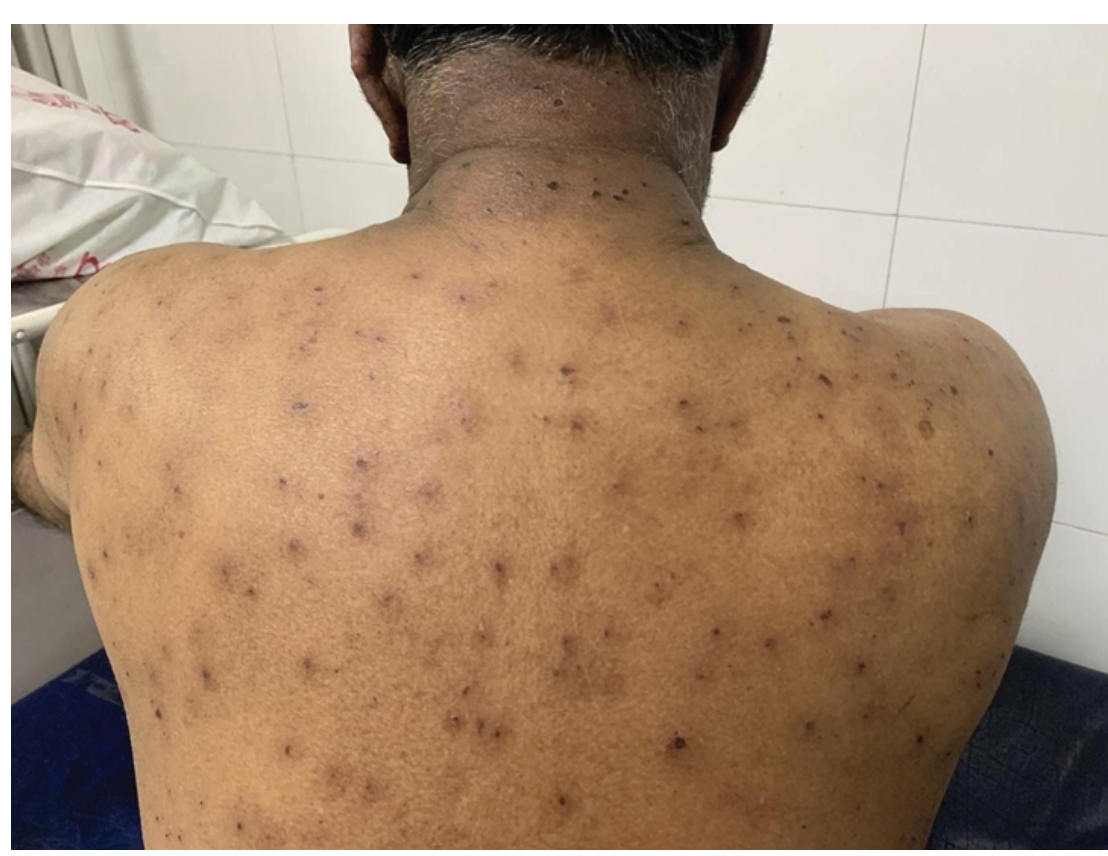

Figure 1: Multiple honey bee sting marks all over back, back of the neck and shoulders.

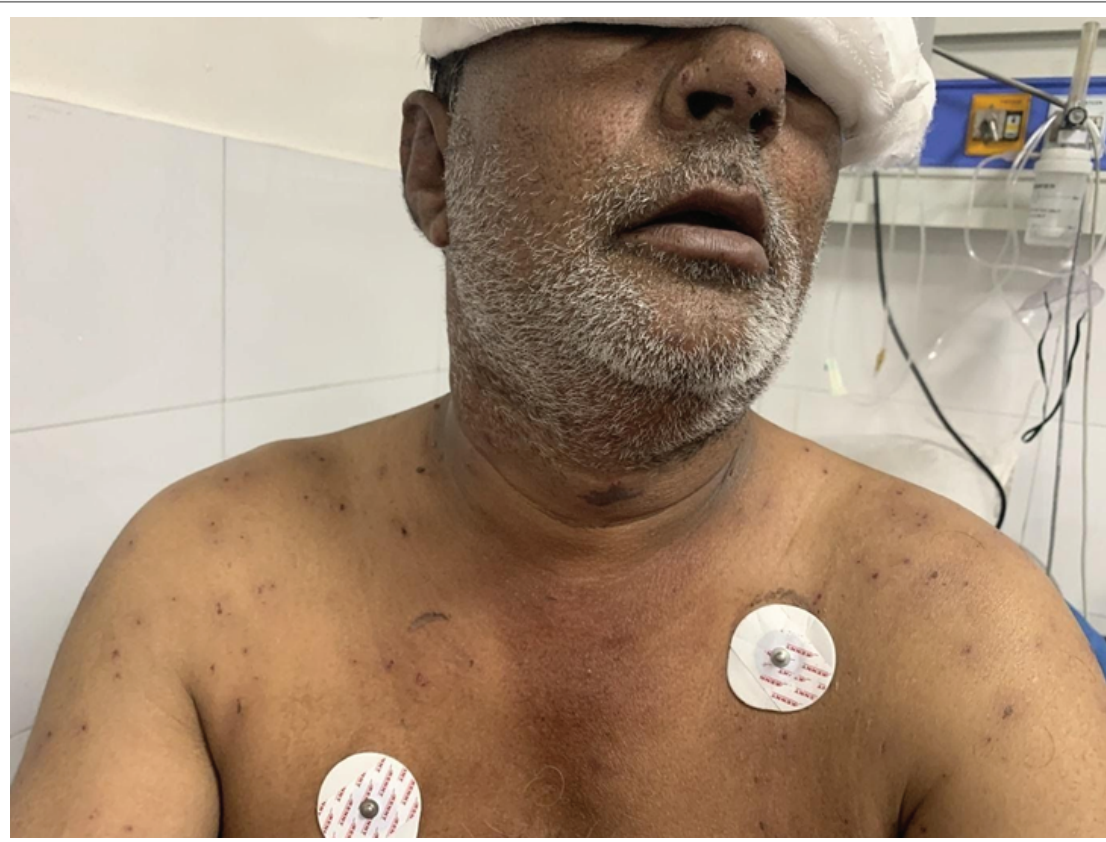

Figure 2: Facial puffiness with multiple honey bee sting marks over nose, face, neck and chest. 
differentiation and a normal size prostate. Thus, a diagnosis of massive honey bee venom induced severe AKI (rhabdomyolysis) was made. The patient's bystanders removed approximately 500 honey bee stings from his face, neck and ears. More than 500 stings were removed from the back. Two stings were removed from external auditory canal by an otorhinolaryngologist.

One sting was removed from the conjunctiva by an ophthalmologist. Tetanus toxoid injection was given. Intravenous saline solution infusion, antibiotics, hydrocortisone and antihistaminic were started. Sodium bicarbonate infusion was started in the view of high anion gap metabolic acidosis. After 24 hour of admission, the patient regained consciousness, but his urine output was only $400 \mathrm{~mL}$ /day, hemodialysis was initiated on an alternate day basis.

After three sessions of hemodialysis, his urine output improved to 1.8 litre/day and serum creatinine was $4.8 \mathrm{mg} / \mathrm{dL}$. Discharge of the patient was done on the twelfth day of admission with a serum creatinine level of $3.9 \mathrm{mg} / \mathrm{dL}$. Serum creatinine was $1.5 \mathrm{mg} / \mathrm{dL}$ after 2 weeks of discharge which subsequently reduced to $1.1 \mathrm{mg} / \mathrm{dl}$ after one month of follow up.

\section{Discussion}

AKI occurs approximately after $24 \mathrm{hrs}$ of the honey bee sting, because of the excess amount of injected poison via the stings [10]. Clinical presentations may be nausea, vomiting, myalgia, joint pain, anuria, oliguria macroscopic hematuria. The direct toxic effect of bee venom can lead to other clinical manifestations like generalized edema, restlessness, headache, hyperventilation (acid breathing), stupor, altered sensorium and severe respiratory failure [10]. Our patient presented after 48 hours of honey bees attack with oliguria, passage of cola colour urine, restlessness, hyperventilation and in a semi-comatose state.

Different studies from discrete parts of the world have reported that honey bees can cause massive attacks and there is a concord that the number of stings is directly related to severe complications like hemolysis, rhabdomyolysis, hepatic involvement, coagulation disturbance, arterial hypotension and ischemic injury to vital organs $[5,11,12]$. Our patient had low blood pressure, high serum SGOT, SGPT, high serum creatine phosphokinase (CPK) level, high urinary myoglobin level and high anion gap metabolic acidosis.

Severe AKI in our patient might be due to the low blood pressure because of the direct vasoactive toxic effect of honey bee venom and myoglobinuria was the presentation of rhabdomyolysis. Rhabdomyolysis was confirmed with increased serum creatine phosphokinase and serum LDH levels [10]. There is some clinical proof that renal tubules can be damaged directly by the bee venom toxins [10]. There is a well known association between rhabdomyolysis and AKI. Myoglobinuria can cause severe AKI in patients having low blood pressure, dehydration and increased serum creatine phosphokinase levels [6]. Precipitation of haemoglobin and myoglobin casts may cause pigment nephropathy in the renal tubules that ultimately leads to acute tubular necrosis [6]. Patients having more than fifty bee stings may show systemic toxic effects of venom [12]. Approximately five hundred honey bee stings have been considered as potentially lethal to a person and the direct systemic effect of the venom may cause death of the victim [11]. The number of stings seems to be directly related to the severity of AKI because the patients having more than one thousand stings had higher creatinine levels in most of the cases [10].

Our patient had more than one thousand honey bee stings all over his body and developed severe AKI. The removal of honey bee sting is the foremost point to remember. Removal of stings should be executed as early as possible because, more prolonged the sting to skin contact time, higher the venom concentration inside the tissues of the victim [10].

Squeezing of the sting should be avoided during removal from the patient's body [10]. In our case, most of the stings were removed on the day of the massive honey bee attack by the patient's attendants and some stings were removed after two days of attack inside the hospital. Two stings were removed from the external auditory canal and one sting was removed from the eye.

Treatment should be given as soon as possible to the patient to avoid severe AKI because, prognosis of the patient in terms of AKI can be calculated by the time interval between the massive honey bee attack and the initiation of treatment. Renal failure was mild and easily reversible in those patients where the treatment was initiated within half an hour of honey bee attack, while severe AKI developed in the patients who got conservative treatment several hours after a massive honey bee stings attack [6].

Our patient was brought to our hospital after 48 hours of a massive honey bee attack and that might be one of the reasons for the development of severe AKI. Till date, no specific serum is available for the bee venom attack [10]. Causes of death may by respiratory failure, severe AKI, acute myocardial infarction or anaphylactic shock [10]. The patients who survive after a honey bee stings attack usually have good prognosis and there seems to be a full renal recovery in most of the cases [10]. Hemodialysis corrected the high anion gap metabolic acidosis, eliminated the main low molecular weight bee venom toxin, mellitin, and played an important role in saving the life of our patient [10].

\section{Conclusion}

The victims of an attack of multiple honey bee stings are actually medical emergency patients. Stings should be removed from the patient's body as soon as possible to decrease the exposure time to the venom. Hemodialysis can eliminate the low molecular weight bee venom toxin and is life-saving in severe acute kidney injury caused by multiple honey bee stings.

\section{Acknowledgement}

The authors express their gratitude to the patient and his guardians for full cooperation during prolonged hospital stay and providing medical records for preparing this manuscript. We express sincere thanks to Dr Rajesh J for helping in revision of manuscript.

\section{Statement of Ethics}

The authors followed the guidelines for human studies and the research was conducted ethically. Information revealing the subject's identity was avoided. Guardians have given their written informed consent to publish this case, including publication of images.

\section{Disclosure Statement}

The authors have no conflicts of interest to declare.

\section{Funding Sources}

The authors declare that they have no financial interests related to the material in the manuscript.

\section{Author Contributions}

Satyanand Sathi and Anil Kumar Garg contributed to Manuscript design, data interpretation, manuscript review and drafting of 
the manuscript. Jaipal Chand and Arvind Trivedi contributed to manuscript review. Manoj Kumar Singh and Virendra Singh Saini contributed to final drafting and critical revision of the manuscript. All the authors approved the final version of the manuscript.

\section{References}

1. Tumwine JK, Nkrumah FK (1990) Acute renal failure and dermal necrosis due to bee stings: report of a case in a child. Cent Afr J Med 36: 202-204

2. Daher Ede F, da Silva Júnior GB, Bezerra GP, Pontes LB, Martins AM, et al. (2003) Acute renal failure after massive honeybee stings. Rev Inst Med Trop Sao Paulo 45: 45-50.

3. Daisley H (1998) Acute haemorrhagic pancreatitis following multiple stings by Africanized bees in Trinidad. Trans R Soc Trop Med Hyg 92: 71-72.

4. Gabriel DP, Rodrigues AG Jr, Barsante RC, dos Santos Silva V, Caramori JT, et al. (2004) Severe acute renal failure after massive attack of Africanized bees. Nephrol Dial Transplant 19: 2680.

5. Franca FO, Benvenuti LA, Fan HW, Dos Santos DR, Hain SH, et al. (1994) Severe and fatal mass attacks by 'killer' bees (Africanized honey bees--Apis mellifera scutellata) in Brazil: clinicopathological studies with measurement of serum venom concentrations. Q J Med 87: 269-282.
6. Daher EF, Silva Junior GB, Bezerrra GP, Pontes LB, Martins AMC, et al. (2003) Case report: Acute renal failure after massive honey bee stings. Rev Inst Med trop S Paulo 45: 45-50.

7. Mejia G, Arbelaez M, Henao JE, Sus AA, Arango JL (1986) Acute renal failure due to multiple stings by Africanized bees. Ann Intern Med 104: $210-211$

8. Ghassemi K, Esteghamati M, Moayedi AR, Alavi SL (2013) Acute renal failure after multiple honeybees' Stings (Case Report). Asian J Med Pharm Res 3: 148-149.

9. Deshpande PR, Farooq AK, Bairy M, Prabhu RA (2013) Acute Renal Failure and/or Rhabdomyolysis due to Multiple Bee Stings: A Retrospective Study. N Am J Med Sci 5: 235-239.

10. Silva GBD Junior, Vasconcelos AG Junior, Rocha AMT, Vasconcelos VR, Barros J Neto, et al. (2017) Acute kidney injury complicating bee stings - a review. Rev Inst Med Trop Sao Paulo 59: e25.

11. Díaz-Sánchez CL, Lifshitz-Guinzberg A, Ignacio-lbarra G, HalabeCherem J, Quinones-Galvan A (1998) Survival after massive (>2000) Africanized honeybee stings. Arch Intern Med 158: 925-927.

12. Thiruventhiran T, Goh BL, Leong CL, Cheah PL, Looi LM, et al. (1999) Acute renal failure following multiple wasp stings. Nephrol Dial Transplant 14: 214-217. 